\title{
An Improved Method for the Purification of Carbonic Anhydrase Isozymes by Affinity Chromatography
}

Methods for purifying carbonic anhydrase (EC 4.2.1.1.) isozymes, carbonic anhydrase B (or I) and C (or II), by affinity chromatography have been described by Falkbring et al. (1) and Whitney (2), in which affinity gels are formed by coupling, respectively, $p$-aminobenzenesulfonamide, and $p$-(aminomethyl)benzenesulfonamide to Sepharose polysaccharides by means of cyanogen bromide activation. Attempts to repeat these methods in our laboratory were not satisfactory as the reproducibility and yields were variable. It is possible that the susceptibility of the linkage to esterase hydrolysis by carbonic anhydrase could account for this variability. It has been suggested (3) that the linkage given by cyanogen bromide activation is of an ester type, i.e., $-\mathrm{C}-\mathrm{O}-\mathrm{CO}-\mathrm{NH}-R$, where $R$ represents a functional group, and it was possible to hydrolyse this linkage by heating at about $80^{\circ} \mathrm{C}$ and $\mathrm{pH}$ values between 8 and 12 . When purified carbonic anhydrase at $\mathrm{pH} 9.0$ was passed through columns of this type of gel, cleavage of the sulfonamides occurred; and in particular, the cleavage products were readily observed when highly colored azosulfonamides were coupled. Also the total distance of the coupled inhibitor from the gel matrix, given by these methods, does not exceed the depth of the active site cleft (4). Therefore, to overcome these factors, gels were prepared by coupling sulfonamides to CM Sephadex using a water-soluble carbodiimide (5) to form a peptide bond between the carboxyl and amino groups. Two sulfonamide inhibitors were used, $p[(2,4$-diaminophenyl)azo $]$ benzenesulfonamide (Prontosil), and $p$-(aminomethyl)benezenesulfonamide. The azosulfonamide coupled gel had the advantages of a higher capacity and a red-colored product that enabled visual estimation of coupling efficiency.

For recent reviews of carbonic anhydrase isozymes see Lindskog et al. (6), and Carter (7).

\section{METHODS}

CM Sephadex was obtained from Pharmacia and all other reagents from Aldrich. Prontosil was prepared by diazotization of $p$-aminobenzenesulfonamide and coupling to $m$-phenylenediamine as previously described (8). The affinity gel was prepared by coupling the sulfonamide to CM Sephadex by the method of Hoare and Koshland (5). Ten grams of CM Sephadex (C50 coarse grade) was added to $300 \mathrm{ml}$ of $50 \%$ ace- 
tone containing $5 \mathrm{~g}$ of the sulfonamide. The $\mathrm{pH}$ was adjusted to 4.75 , and $5 \mathrm{~g}$ of 1-(3-dimethylaminopropyl)-3-ethylcarbodiimide $\mathrm{HCl}$ (freshly dissolved in $10 \mathrm{ml}$ of $\mathrm{H}_{2} \mathrm{O}$ ) was added dropwise to the stirred suspension, maintaining $\mathrm{pH} 4.75$ by the addition of $1 \mathrm{M} \mathrm{H}_{2} \mathrm{SO}_{4}$. The reaction mixture was gently stirred overnight at $22^{\circ} \mathrm{C}$. The gel was washed in a $600 \mathrm{ml}$ coarse Buchner funnel using, progressively, acetone, 50\% acetone, and hot water at $\mathrm{pH} 10$, until free of excess inhibitor.

The capacities of the gels were determined in the following manner. Approximately $2 \mathrm{ml}$ of affinity gel equilibrated in $0.1 \mathrm{M} \mathrm{Tris}-\mathrm{SO}_{4} / 0.2 \mathrm{M}$ $\mathrm{Na}_{2} \mathrm{SO}_{4} \mathrm{pH} 9.0$ was equilibrated with $90 \mathrm{mg}$ of purified human carbonic anhydrase $B$ and then transferred to a $1.5 \mathrm{~cm}$ i.d. column. The excess enzyme was eluted and the amount determined using a molar extinction value of $49,000 \mathrm{M}^{-1} \mathrm{~cm}^{-1}$ at $280 \mathrm{~nm}$. The bound enzyme was eluted with $0.4 \mathrm{M} \mathrm{KI} / 0.1 \mathrm{M}$ Tris- $\mathrm{SO}_{4}, \mathrm{pH} 7.0$, and the amount determined as above. Finally the gel was transferred to a tared $20 \mathrm{ml}$ Buchner funnel, dried by repeated washing with acetone, and the quantity of dry gel determined. In order to determine the amount of coupled inhibitor the spectra of the two types of affinity gel, in $0.1 \mathrm{M}$ Tris- $\mathrm{SO}_{4} / 0.2 \mathrm{M} \mathrm{Na}_{2} \mathrm{SO}_{4}$ at $\mathrm{pH} 7.5$, were recorded between $700-200 \mathrm{~nm}$ using a Beckman recording spectrophotometer and $1 \mathrm{~mm}$ cells against a reference of uncoupled CM Sephadex in the same buffer. The spectra of the free inhibitors, at $\mathrm{pH}$ 7.5 , and several concentrations were also recorded using $1 \mathrm{~cm}$ cells.

For the large-scale preparation of human carbonic anhydrase isozymes, $250 \mathrm{ml}$ of washed, packed red cells was lysed with water $(1: 2)$ and the $\mathrm{pH}$ adjusted to 6.0 with $1 \mathrm{~N} \mathrm{H}_{2} \mathrm{SO}_{4}$ to precipitate the cell stroma, which was removed by centrifugation at $16,000 \mathrm{~g}$ for $30 \mathrm{~min}$. The stroma-free lysate was extensively dialyzed against water, the $\mathrm{pH}$ adjusted to 9.0 with $0.2 \mathrm{~N} \mathrm{NaOH}$, and any further precipitate removed by centrifugation at $16,000 \mathrm{~g}$ for $30 \mathrm{~min}$. The lysate was pumped through a column $(2.5 \times 20 \mathrm{~cm})$ of affinity gel equilibrated in $0.2 \mathrm{M}$ Tris-SO ${ }_{4}$ buffer $\mathrm{pH}$ 9.0 , at a flow rate of $35-40 \mathrm{ml} / \mathrm{hr}$. Nonspecifically bound protein was eluted with $0.1 \mathrm{M}$ Tris- $\mathrm{SO}_{4} / 0.2 \mathrm{M} \mathrm{Na}_{2} \mathrm{SO}_{4}$ buffer solution at $\mathrm{pH}$ 9.0, until the absorbance at $280 \mathrm{~nm}$ was zero. Carbonic anhydrase $\mathbf{B}$, the low activity isozyme, was specifically eluted with $0.4 \mathrm{M} \mathrm{KI} / 0.1 \mathrm{M}$ Tris $-\mathrm{SO}_{4}$ $\mathrm{pH} 7.0$, and carbonic anhydrase $\mathrm{C}$, the high activity isozyme, with $0.2 \mathrm{M}$ $\mathrm{KCN} / 0.1 \mathrm{M}$ Tris $-\mathrm{SO}_{4} / 0.2 \mathrm{M} \mathrm{Na}_{2} \mathrm{SO}_{4} \mathrm{pH}$ 7.5. The eluted enzymes were tested for purity by starch gel electrophoresis (9), and by immunodiffusion on agar plates (10). To check for the completeness of binding of the isozymes, the eluted hemolysate was tested for carbonic anhydrase by a specific esterase assay (11). Carbonic anhydrase isozymes from the red cells of rhesus macaque, chimpanzee, dog, cat, pigeon, chicken, and duck were purified in a similar way, except that the avian red cells were processed in the presence of $10 \mathrm{~mm}$ cysteine and were lysed using a $1: 3$ 
ratio with water. Alternatively, a batchwise procedure was used for the large-scale purification of carbonic anhydrase. The dialyzed, stroma-free lysate at $\mathrm{pH} 9.0$ was equilibrated with affinity gel for at least $3 \mathrm{hr}$, and the gel washed free of the majority of nonspecifically bound protein in a Buchner funnel with $0.1 \mathrm{M}$ Tris- $\mathrm{SO}_{4} / 0.2 \mathrm{M} \mathrm{Na}_{2} \mathrm{SO}_{4} \mathrm{pH}$ 9.0. The gel-enzyme complex was transferred to a column to complete the washing and the isozymes eluted as above.

\section{RESULTS}

Two separate batches of affinity gel were used by coupling Prontosil, and also two batches by coupling $p$-(aminomethyl)benzenesulfonamide, to C50 CM Sephadex. The swollen gel capacity was estimated from that for the dry gel by assuming that $1 \mathrm{~g}$ of dry gel gave $18 \mathrm{ml}$ of swollen gel, at $\mathrm{pH}$ 9.0, in $0.1 \mathrm{M}$ Tris- $\mathrm{SO}_{4} / 0.2 \mathrm{M} \mathrm{Na}_{2} \mathrm{SO}_{4}$. The spectra of the free and coupled Prontosil showed a broad absorption maximum at $500-400 \mathrm{~nm}$, and a sharper minimum at $300 \mathrm{~nm}$. Because of the high absorbance of the Prontosil-coupled gel at $500-400 \mathrm{~nm}$ the absorption minimum at 300 $\mathrm{nm}$ was used to estimate coupling yield. From the free Prontosil a molar extinction coefficient was determined of $34,000 \mathrm{M}^{-1} \mathrm{~cm}^{-1}$ at $300 \mathrm{~nm}$ and $\mathrm{pH} 7.5$, and this was used to calculate the amount of coupled inhibitor. The spectra of the free and coupled $p$-(aminomethyl)benzenesulfonamide both showed a characteristic peak at $267 \mathrm{~nm}$, and this wavelength was used to quantitate the coupled inhibitor, using a molor extinction coefficient of $7400 \mathrm{~m}^{-1} \mathrm{~cm}^{-1}$ at $267 \mathrm{~nm}$ and $\mathrm{pH}$ 7.5. The capacities coupling yields and binding efficiencies are shown in Table 1. The results obtained for the amounts of coupled inhibitor indicate that of the total carboxyl groups on the Sephadex ion exchanger about $2.4 \%$

TABLE 1

Carbonic anhydrase Capacities and Binding Efficiencies of the AFFINITY Gels

\begin{tabular}{lcccc}
\hline \multicolumn{1}{c}{ Affinity gel } & $\begin{array}{c}\text { Enzyme } \\
\text { capacity } \\
(\mathrm{mg} / \mathrm{g} \\
\text { dry gel) }\end{array}$ & $\begin{array}{c}\text { Enzyme } \\
\text { capacity } \\
(\mathrm{mg} / \mathrm{ml} \\
\text { gel" }^{\prime \prime}\end{array}$ & $\begin{array}{c}\text { Coupled } \\
\text { inhibitor } \\
(\mu \mathrm{moles} / \\
\mathrm{ml} \text { gel })\end{array}$ & $\begin{array}{c}\% \text { Binding } \\
\text { efficiency }\end{array}$ \\
\hline $\mathrm{CM}$-Prontosil & 300 & 17 & 6.5 & 9 \\
$\mathrm{CM}-\mathrm{p} \mathrm{NH}_{2} \mathrm{CH}_{2} \mathrm{C}_{6} \mathrm{H}_{4} \mathrm{SO}_{2} \mathrm{NH}_{2}$ & 420 & 23 & 5.5 & 14 \\
& 244 & 14 & 27.5 & 2 \\
\hline
\end{tabular}

"Based on estimate that $1 \mathrm{~g}$ of dry gel gives $18 \mathrm{ml}$ of swollen gel.

${ }^{b}$ Defined as \% ratio of observed carbonic anhydrase capacity $(\mu \mathrm{moles} / \mathrm{ml}$ gel) to coupled inhibitor ( $\mu$ moles $/ \mathrm{ml}$ gel). 


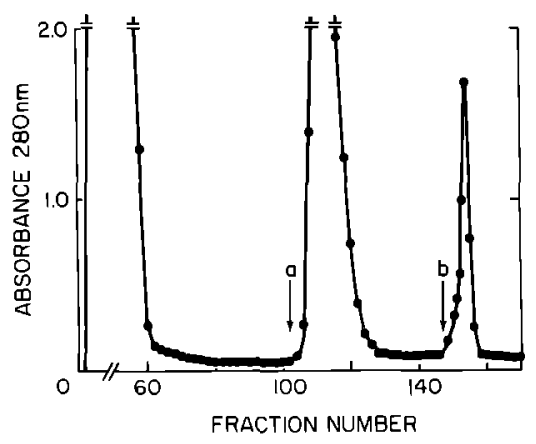

Fig. 1. Affinity chromatography of $250 \mathrm{ml}$ of packed human red cells $(800 \mathrm{ml}$ of treated hemolysate) using a CM-Prontosil gel, and a $2.5 \times 20 \mathrm{~cm}$ column with a $38 \mathrm{ml} / \mathrm{hr}$ flow rate and $19 \mathrm{ml}$ fraction volumes. (a) Indicates the first elution of KI, and (b) the first elution of KCN. Fractions 106-123 contain pure carbonic anhydrase $B$, and its secondary isozyme and fractions $148-156$ pure carbonic anhydrase C. For details see the text.

are coupled in the Prontosil gel, and about $12.2 \%$ in the $p$-(aminomethyl)benzenesulfonamide gel.

Figure 1 shows the elution profile obtained from the purification of $250 \mathrm{ml}$ of packed human red cells, which gave a yield of $360 \mathrm{mg}$ of carbonic anhydrase $B$ and $55 \mathrm{mg}$ of carbonic anhydrase C. These preparations of the major isozyme forms also included much smaller amounts of their respective secondary isozymes. Starch gel electrophoresis of the pooled concentrated peaks, followed by staining for protein, and $\mathrm{CO}_{2}$ hydratase and esterase activity, showed that the first peak contained pure carbonic anhydrase B, and the second pure carbonic anhydrase $\mathrm{C}$. Also immunodiffusion gels using anti-human carbonic anhydrase $\mathrm{B}$ and anti-human carbonic anhydrase $\mathrm{C}$, prepared from rabbit serum, indicated that each peak contained only the one component isozyme. The eluted hemolysate showed no carbonic anhydrase activity when assayed with $p$-nitrophenyl acetate. Carbonic anhydrases from red cells of the rhesus macaque, chimpanzee, dog, cat, pigeon, chicken, and duck, were also purified by this method. Of these species only the rhesus macaque and chimpanzee possess both high and low activity isozymes, and their red cells were treated in an identical manner to those of human to give pure carbonic anhydrase $B$ and carbonic anhydrase $C$ isozymes and their respective secondary isozymes. The other species have only one major form of carbonic anhydrase and the eluting conditions were as follows: dog, pigeon, and duck, $0.4 \mathrm{M} \mathrm{KI} / 0.1 \mathrm{M}$ Tris-SO $\mathrm{SO}_{4}$ 7.0; cat and chicken, $0.2 \mathrm{M} \mathrm{KCN} / 0.1 \mathrm{M}$ Tris- $\mathrm{SO}_{4} / 0.2 \mathrm{M} \mathrm{Na}_{2} \mathrm{SO}_{4} \mathrm{pH}$ 7.5. A further indicator of the purity of these preparations was the single sequences obtained, from C-terminal analyses using carboxypeptidase, of cat, dog, chicken, pigeon, and duck isozymes (12). The starch gel patterns of 


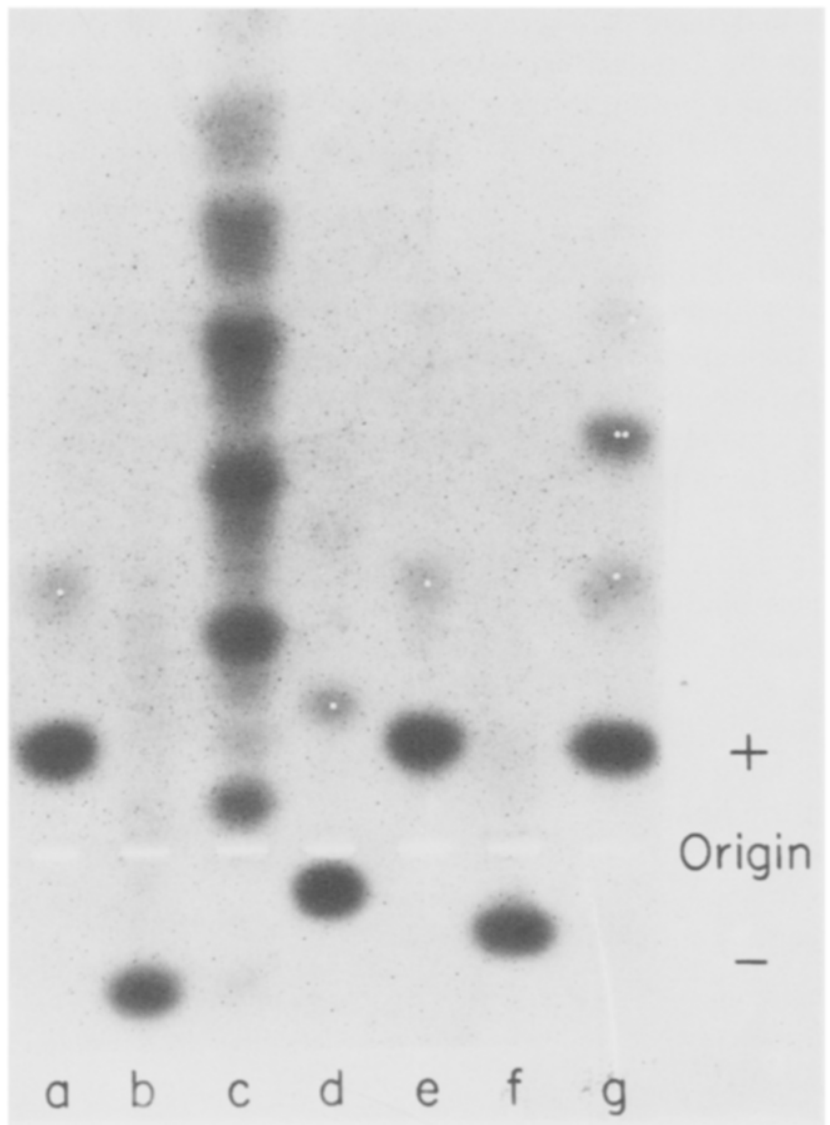

FIG. 2. Starch gel electrophoresis patterns of carbonic anhydrase isozymes purified by affinity chromatography. Vertical electrophoresis was at $4^{\circ} \mathrm{C}$ in $20 \mathrm{~mm}$ sodium borate buffer, $\mathrm{pH} 8.5$, and $0.3 \mathrm{~m}$ sodium borate bridge buffer, $\mathrm{pH} 8.0$ (containing $30 \mathrm{~mm} \mathrm{NaCl}$ ), for $21 \mathrm{hr}$ at $8 \mathrm{~V} / \mathrm{cm}$. Gels were stained with $0.4 \%$ nigrosin. (a) Human carbonic anhydrase $B$; (b) human carbonic anhydrase $C$; (c) human carbonic anhydrase $C$ eluted with KOCN; (d) rhesus macaque carbonic anhydrase B; (e) chimpanzee carbonic anhydrase $B$; (f) cat carbonic anhydrase; (g) dog carbonic anhydrase. The secondary isozymes are indicated by single white dots, and a variant of the dog enzyme by a double white dot.

some purified carbonic anhydrases are shown in Fig. 2. The elution of carbonic anhydrase $\mathrm{C}$ with cyanate ion gave multiple bands, probably due to its reaction with amino groups (13), resulting in a net reduction in positive charge for each reacted amino groups.

\section{DISCUSSION}

This method gives a stable, high capacity affinity gel suitable for the purification of carbonic anhydrase from a variety of sources. The two gel 
types described have been reused several times with no loss of efficiency, with the azo-derived gel having the advantages of higher capacity, and a colored product that enables coupling to be assessed visually. The separation of the secondary isozymes from the major forms of the isozymes requires the use of ion-exchange columns, but these can be small and efficient as only pure isozymes will be chromatographed. The separation and characterization of these secondary isozymes has been discussed by Funakoshi and Deutsch (14). The higher yields of the azo gels can be explained by the length of the coupled inhibitor. Erlich et al. (4), using spin-labeled sulfonamides, investigated the active site clefts of the human isozymes and concluded that they were about $140 \mathrm{~nm}$ deep. The ligand of the azo-coupled gel is about $183 \mathrm{~nm}$ long and therefore is well in excess of this value, whereas the $p$-aminobenzenesulfonamide derived gel produces a ligand of about $125 \mathrm{~nm}$, and this may account for its low ratio of binding capacity to coupled inhibitor. The use of cyanate to release bound enzyme as in the method of Falkbring et al. (1) is not appropriate because of its reaction with amino groups. For large-scale purifications, e.g., $>100 \mathrm{ml}$ of packed red cells, batchwise procedures are recommended for the initial binding of enzyme.

Finally, if the linkage given by the cyanogen bromide coupling procedure is susceptible to esterase hydrolysis, then any affinity matrix prepared with this coupling technique could be altered when used with starting material containing esterase activity.

\section{ACKNOWLEDGMENT}

This work was supported by Grant GM-15419 of the U.S. Public Health Service.

\section{REFERENCES}

1. Falkgring, S. O., Gothe, P. O., Nyman, P. O., Sundeerg, L., and Porath, J. (1972) FEBS Lett. 24, 229-235.

2. Whitney, P. L. (1974) Anal. Biochem. 57, 467-476.

3. Bartling, G. J., Brown, H. D., Forrester, L. J., Koes, M. T., Mather, A. N., AND Stasin, R. O. (1972) Biotechnol. Bioeng. 14, 1039-1044.

4. Erlich, R. H., Starkweather, D. K., and Chignell, C. F. (1973) Mol. Pharmacol. 9, 61-73.

5. Hoare, D. G. and Koshland, D. E. (1967) J. Biol. Chem. 242, 2447-2453.

6. Lindskog. S., Henderson, L. E., Kannan, K. K., Liluas, A., Nyman, P. O., and Strandberg, B. (1971) in The Enzymes (Boyer, P. D., ed.), p. 587, Academic Press. New York.

7. Carter, M. J. (1972) Biol. Rev. Cambridge Phil. Soc. 47, 465-513.

8. Yoshninobu, 1., Ojima, S., and Yasawa, T. (1937) J. Pharma. Soc. (Japan) 57, 592-597.

9. Tashian, R. E. (1969) in Biochemical Methods in Red Cell Genetics (Yunis J. J., ed.) pp. 307-336, Academic Press, New York.

10. Tashian, R. E., Shreffler, D. C., and Shows, T. B. (1968) Ann. N. Y. Acad. Sci. 151, 64-77. 
11. Osborne, W. R. A. And Tashian, R. E. (1974) Biochem. J. 141, 219-225.

12. Tashian, R. E., Goodman, M., Tanis, R. J., Ferrell, R. E., and Osborne, W. R. A., in Proc. 3rd International Isozyme Conference (Markert, C. L., ed.), Academic Press, New York, in the press.

13. Stark, G. R., and Smyth, O. G. (1963) J. Biol. Chem. 238, 214-226.

14. Funakoshi, S. And Deutsch, H. F. (1969) J. Biol. Chem. 244, 3438-3446.

William R. A. Osborne

RICHARD E. TASHIAN

Department of Human Genetics,

University of Michigan Medical School

Ann Arbor, Michigan 48104

Received July 1, 1974; accepted September 19,1974 